ensure that childr $\in \mathbf{n}$ leaving school and entering industry are not given jobs making heavy demands on defective eyesight. (3) Facilities for expert ccnsultaticn and treatment of infecticns respcnsible for blindness shculd be increased. (4) Travelling expenses should be defrayed to treatment centres, of both the patient and a companicn.

\section{The Faraday Society}

THe Faraday Society has arranged a discussion on "Modes of Drug Action", to be held at the Hotel Rembrandt, London, S.W.7, on September 24 . There will be morning and afternoon sessions, at which intrcductory addresses will be given by Prof. J. H. Gaddum and Prof. E. K. Rideal, devoted respectively to biological and physico-chemical aspects of the subject.

\section{Association for Scientific Photography}

THE first meeting of the session for 1943-44 of the Associaticn for Scientific Photcgraphy will be held on September 18 at the Middlesex Hospital, London, W.1, to discuss papers on clinical photography. Future meetings will be held monthly ; the October meeting will deal with the use of photographically sensitized metal, wood and plastics in industry, the November meeting with oscillographic recording, and the December meeting will be devoted to an exhibition of scientific photographic apparatus arranged jointly with the Scientific and Technical Group of the Royal Photographic Society. Further particulars can be obtained from the honorary secretary of the Association, Tavistock House North (lst floor), Tavistock Square, London, W.C.I.

\section{ASLIB Conference}

The ASLIB Conference, 1943, to be held in the rocms of the Royal Society, Burlington House, London, W.1, during September 18-19, has been designed to provide a platform for discussion of some of the outstanding problems of the rehabilitation of special library and information services after the War, chiefly to give a lead to immediate action. The whole cf Saturday afternocn has been given to a sympcsium on rehabilitation and it is hoped that the discussicn will bring the British, American and European needs and opportunities into proper relationship. At the inaugural meeting of the Conference, Prof. J. D. Bernal, as a man of science who has always placed a high value on the positive function of information services at the centre of scientific activity, will draw a picture of what must be expected of information services if they are to fulfil this positive functicn in the scientific life of the post-war world. Further information can be obtained from the Secretary, ASLIB, 31, Museum Street, London, W.C.1.

\section{Miners' Welfare Scholarships and Exhibitions}

The Trustees of the Miners' Welfare National Scholarships and Students' Exhibitions Funds announce the award of nineteen scholarships and nine exhibitions in 1943, as follows :

Scholarships :

Francis D. Davies, of Dinnington, Yorkshire, tenable at the University of Sheffield; Kingsley $\mathbf{R}$. Fox, of Fenay Bridge, Yorkshire, tenable at the University. of Leeds ; Geoffrey F. Gill, of Barnsley, Yorkshire, tenable at the University of Sheffield; Raymond Hall, of Bakestone Moor, Nottinghamshire, tenable at the University of Sheffield, for honours degree courses in mining; Robert H. Kirkup, of
Radeliffe, Northumberland, tenable at King's College, University of Durham, for an honours degree course in electrical engineering; Edward M. Robson, of Monkseaton, Northumberland, tenable at King's College, University of Durham, for an honours degree course in mining; Ernest Blewitt, of Cudworth, Yorkshire, tenable at Selwyn College, University of Cambridge, for an honours degree ccurse in natural science; Ben R. Brown, of Swinton, Yorkshire, tenable at the University of Manchester, for an honours degree course in chemistry ; Jeffrey Ellison, of Old Sharlston, Yorkshire, tenable at the University of Leeds, for an honours degree course in colour chemistry ; James B. Finean, of Wombwell, Yorkshire, tenable at the University of Birmingham, for an honours degree course in chemistry; Thomas G. Griffiths, of Cilfrew, Glamorganshire, tenable at Queen's College, University of Oxford, for an honours degree course in modern languages; Jean Haswell, of Clipstone, Nottinghamshire, tenable at the University of Reading, for an honours degree course in English; Joseph Hutchinson, of Kimblesworth, Co. Durham, tenable at King's College, University of Durham, for a degree course in dental surgery ; Harry O. Morton, of Balby, Yorkshire, tenable at King's College, University of Cambridge, for an honours degree course in natural science; Thomas A. I. Tees, of Twyn, Carmarthenshire, tenable at the University College, Cardiff, for a degree course in medicine; Mavis Sheppard, of New Ollerton, Nottinghamshire, tenable at King's College, University of London, for an honours degree course in English; Gordon B. Skingle, of Chesterfield, Derbyshire, tenable at University College, Durham, for an honours degree course in modern languages; Graham Turner, of Shuttlewood, Derbyshire, tenable at Queens' College, University of Cambridge, for an honours degree course in natural science; Paul A. N. Wainwright, of Billinge, Lancashire, tenable at the University of St. Andrews, for a degree course in medicine.

\section{Exhibitions :}

Harry Allison, of New Herrington, Co. Durham, tenable at King's College, University of Durham, for an honours degree course in agriculture ; Drummond. H. Bowden, of Abercynon, Glamorganshire, tenable at the University of Bristol, for a degree course in medicine; Bridget Cairns, of Kelty, Fifeshire, tenable at the University of Edinburgh, for an honours degree course in physics ; Henry P. Clement, of Willington, Co. Durham, tenable at King's College, University of Durham, for an honours degree course in chemistry; Kathleen M. Dawson, of Newbiggin-bySea, Northumberland, tenable at St. Hilda's College, University of Durham, for a course for the diploma in education ; David Jenkins, of Llanharan, Glamorganshire, tenable at the University College of Wales, Aberystwyth, for an honours degree course in geography ; Betty M. Linford, of Royston, Yorkshire, tenable at Newnham College, University of Cambridge, for an honours degree course in history; Jean M. McLachlan, of Girvan, Ayrshire, tenable at the University of Glasgow, for an honours degree course in chemistry; Henry A. Rigby, of Swinton, Yorkshire, tenable at Exeter College, University of Oxford, for an honours degree course in chemistry.

Erratum. In the article "Edmond Halley and Geomagnetism" in NATure of August 28, on p. 232, col. 1, line 6, for "shell" read "skill". 